\title{
Bathymetric demography, enzyme activity patterns, and bioenergetics of deep-living scorpaenid fishes (genera Sebastes and Sebastolobus): paradigms revisited
}

\author{
Russell D. Vetter*, Eric A. Lynn \\ National Oceanic and Atmospheric Administration, Southwest Fisheries Science Center, La Jolla, California 92038, USA
}

\begin{abstract}
Previous metabolic studies of scorpaenid fishes have measured inter-and intra-specific differences in physiological and biochemical capacities in fishes living at different depths. Small sample sizes and undocumented provenance of the samples studied have not allowed a full examination of the environmental basis for metabolic adaptation. The objective of this study was to determine the bathymetric demography of 22 scorpaenid fushes of the genera Sebastes and Sebastolobus, and to examine inter- and intra-specific changes in metabolıc capacity in 4 of them (Sebastes goodei, Sebastes diploproa, Sebastolobus alascanus and Sebastolobus altivelis) representative of different environmental conditions. We attempted to collect samples that spanned the tull depth and size ranges of each species. We examined changes in metabolic capacity as it was affected by size, depth of occurrence, and the existence of an oxygen minimum zone (OMZ) centered at $800 \mathrm{~m}$. Lactate dehydrogenase (LDH) was measured as an indicator of glycolytic capacity. Citrate synthase (CS), a Krebs cycle enzyme, was measured as an indicator of aerobic capacity. Malate dehydrogenase (MDH), an enzyme which helps maintain redox balance between the mitochondrion and cytosol, was also used as an indicator of aerobic capacity. When normalized to a common size, S. goodei, S. diploproa, S. alascanus and S. altivelis displayed an inter-specific pattern of declining metabolic activity with depth of occurrence. Intra-specific size scaling of glycolytic capacity (LDH) was positive in the shallow-living $S$ goodei. However, no scaling occurred in $S$. diploproa and $S$. alascanus, and negative scaling of glycolytic activity occurred in the deep-living $S$. altivelis. MDH did not scale in S. goodel and $S$. diploproa but was negative in the 2 deeper-living Sebastolobus species. CS activity scaled negatively in S. goodei, S. alascanus, and S. altivelis, but the deep-water specialist, $S$. altivelis, had the steepest slope. S. altivelis was the only species where similar-sized individuals could be compared over a wide depth range. There was no elcvation of LDH, or increase in anaerobic poise, in response to the hypoxia of the OMZ. Rather, all 3 enzyme activities were highest at $600 \mathrm{~m}$ and generally declined with increasing depth. Contrary to the existung paradigm, $S$. alascanus and $S$. altivelis were not found to be shallow- and deep-living congeners. Rather, $S$. altivelis is a permanent resident of deep water, while $S$. alascanus settles in shallow water then migrates to deep water with the onset of sexual maturity. When living in deep water, the supposed shallow water species, $S$. alascanus, maintains higher activities of all enzymes and grows an order of magnitude larger ( $>5000 \mathrm{vs}<500 \mathrm{~g}$ ). In deep-water slope habitats expected patterns of allometric scaling of white muscle enzyme activities appear to be altered by the limitatıons of food and oxygen availability, a pattern previously observed in flatfishes.
\end{abstract}

KEY WORDS: Metabolic adaptation. Deep-sea fishes Oxygen minimum zone Feeding rates Lactate dehydrogenase Citrate synthase - Malate dehydrogenase

\section{INTRODUCTION}

Rockfishes of the genus Sebastes (family Scorpaenidae) are an abundant and diverse group of fishes

•E-mail: rvetter@ucsd.edu that occupy a variety of demersal and pelagic habitats in the North Pacific and North Atlantic. Another scorpaenid genus, Sebastolobus, the thornyheads, is represented by 3 species that are abundant on the North Pacific continental slope. In the northern Pacific, the 2 genera are found in coastal regions from Japan, north- 
ward to the Aleutian Islands and down the west coast of North America to Baja California, Mexico (Miller \& Lea 1972, Eschmeyer et al. 1983). Along the west coast of the United States there are over 70 species of Sebastes and 2 species of Sebastolobus. In many cases the fishes have extensive north-south distributions but relatively narrow depth distributions. Rockfishes occupy a variety of benthic, pelagic, and kelp forest habitats on the continental shelf $(\leq 200 \mathrm{~m}$ ) Deeper on the upper continental slope (200 to $1400 \mathrm{~m}$ ), rockfishes become less common with depth, and the 2 thorny. heads Sebastolobus alascanus and Sebastolobus altivelis become the most common deep-water scorpaenids (Miller \& Lea 1972, Eschmeyer et al, 1983). Almost all rockfish species are highly valued and exploited in recreational and commercial fisheries (Silverthorne \& Jacobson 1995). Thornyhead live too deep for recreational fisheries but are important commercial species (lanelli et al. 1994). Deep-water fisheries on the upper continental slope are expanding and affecting the abundance of thornyheads and some rockfish species that have not been heavily fished previously. The biology and ecology of these deep-water species are insufficiently understood to allow proper management of these new fisheries (Jacobson \& Vetter 1996).

All rockfishes are live-bearing (Wourms 1991), but thornyheads produce bilobed, jellied, egg masses which float to the surface, where hatching occurs (Pearcy 1962). Rockfishes have pelagic larval and juvenile phases which extend for a period of weeks to a few months depending on the species (Moser \& Boehlert 1991), while thornyheads have more protracted pelagic larval and juvenile stages. Sebastolobus alascanus settles at about 1 yr of age 22 to $27 \mathrm{~mm}$ length) and $S$. altivelis remains pelagic for well over 1 yr and settles at 42 to $56 \mathrm{~mm}$ (Moser 1974). Settlement depths for Sebastes species are typically shallower than $100 \mathrm{~m}$ except for deep-water forms such as Sebastes aurora, Sebastes diploproa and Sebastes melanostomus which can have additional pelagic juvenile phases occupying mid-water depths (200 to $250 \mathrm{~m}$ ), and which settle at depths of 200 to $400 \mathrm{~m}$ (Moser \& Boehlert 1991). Few settled juvenile $S$. aldscanus have been collccted, but existing collections and the absence of small juvenile $S$ alascanus in deep trawl hauls indicate that they settle primarily on the shelf at about 100 to $200 \mathrm{~m}$, perhaps over rocky bottom (Moser 1974, Wakefield 1990 , H. G. Moser pers. comm.). In contrast most $S$. altivelis settle at depths between 600 and $1200 \mathrm{~m}$ and juveniles and adults occur at the same depths (Wakefield 1990. Jacobson \& Vetter 1996).

Moser (1974), summarizing incomplete earlier information, gave the depth ranges for Sebastolobus species as between 180 and $440 \mathrm{~m}$ with known extremes of 18 to $1524 \mathrm{~m}$ for the supposed shallow-Iiving form $\mathrm{S}$. alascanus, and between 550 and $1300 \mathrm{~m}$ with known extremes of 200 to $1550 \mathrm{~m}$ for the deep-living form $S$. altivelis. Over the past 15 yr the 2 Sebastolobus species have been used extensively in biochemical and physiological studies of metabolic adaptation of deep-sea fishes because they are morphologically very similar but were believed to have different preferred depth distributions. Factors that have been investigated in either one or both species include: the metabolic consequences of the transition from a pelagic to a benthic existence during settlement (Smith \& Brown 1983, Siebenaller 1984); enzymatic activities in congeners living at different depths (Siebenaller \& Somero 1982); effects of hydrostatic pressure on enzyme activities (Siebenaller \& Somero 1978, 1989, Somero \& Siebenaller 1979, Siebenaller 1983, 1984, Hennessey \& Siebenaller 1985); temperature effects (Siebenaller 1984, Yang et al. 1992); food deprivation (Yang \& Somero 1993), and hypoxia (Yang et al. 1992). Recent reviews and texts summarize many of these results (Siebenaller \& Somero 1989, Somero 1991, 1992). Most of these metabolic studies have not reported the size, or depth of capture, of the specimens examined. Rather they are often compared on the basis of general, unvalidated, life-history properties such as the minimum depth of occurrence of the species (the depth below which $90 \%$ of the population occurs; Childress \& Nygaard 1973).

Recent studies indicate that the bathymetric distribution of the 2 species of Sebastolobus is not as previously assumed, and that $S$. alascanus adults inhabit the same depths as S. altivelis (Wakefield 1990, Jacobson \& Vetter 1996). Because of the expansion of deepwater slope fisheries we decided to reexamine the bathymetric demography, life history, and metabolic adaptations of the 2 Sebastolobus congeners, and compare them to other shallow-and deep-living Sebastes species in order to provide a better understanding of the bioenergetic requirements and ecological interactions of scorpaenid fishes occurring in deep water. We selected a study site in Monterey Bay, California, USA that provided a uniform decline in depth and sampled it systematically from 100 to $1400 \mathrm{~m}$ depth during 3 cruises in January, April and September (Vetter et al. 1994). We measured physical variables including temperature, salinity, and dissolved oxygen. We determined the bathymetric demography of 20 Sebastes species and 2 Sebastolobus species occurring along the shelf-slope continuum. Four species that differed in bathymetric demography. Sebastes goodei, Sebastes diploproa, S. alascanus, and S. altivelis, were chosen to examine the effects of the shelf and slope habitat on bioenergetic characteristics. Individuals of $S$. goodei, $S$. diploproa, $S$. alascanus, and $S$, altivelis of various sizes and from different depths were compared on the 
basis of enzyme activity levels. The activity of the glycolytic enzyme lactate dehydrogenase (LDH) in the white muscle was measured to estimate anaerobic metabolic potential. Malate dehydrogenase (MDH) and citrate synthase (CS) activities were measured as indicators of aerobic potential. CS activity was also used to estimate the daily energy requirements, feeding intervals, and population level differences in energy demand. This, together with an earlier study of flatfishes (Vetter et al. 1994), has clarified our understanding of the bioenergetic constraints on fish production on the continental slope.

\section{METHODS AND MATERIALS}

Collection of fishes. Our study site in Monterey Bay was a transect beginning $11 \mathrm{~km}$ offshore from Santa Cruz, California (100 $\mathrm{m}$ depth). The site was selected for the following reasons: it coincided with the core of the fishes' north-south distribution; the relation between distance from shore and depth was simple; the surface area of habitat at each depth was similar; bottom types (sediment, relief) were relatively uniform; and the weather permitted sampling in all seasons. Trawl stations were about $4 \mathrm{~km}$ apart. Prior to trawling at a depth, a survey track following a uniform depth contour was established based on shipboard bathymetry measurements. Trawling following establishment of a survey track was done at 100, 200,400 $600,800,1000,1200$ and $1400 \mathrm{~m}$ depths. Each tow had a bottom time of $30 \mathrm{~min}$ at $600 \mathrm{~m}$ or shallower, and $1 \mathrm{~h}$ at the deeper stations. The trawl was a polyethylene Aberdeen trawl with $14 \mathrm{~cm}$ mesh at the opening and a $3 \mathrm{~cm}$ mesh bag liner The mouth opening was 14 to $15 \mathrm{~m}$ as determined by a Scanmar net calibration system. The density calculations were adjusted for differences in actual trawl duration. With few exceptions 3 hauls per cruise were completed at each depth. In all, 3 cruises were conducted; in April and September 1991, and January 1992. All cruises were aboard the NOAA vessel 'David Starr Jordan' A diagram of the study site has been presented previously (Vetter et al. 1994).

A complete analysis of species composition was done for each trawl. The data collected included fork length (which is equivalent to total length in Sebastolobus sp.), weight, sex, and reproductive condition. The trawl did not sample small scorpaenids $(<5 \mathrm{~cm}$; Jacobson \& Vetter 1996) quantitatively, although the high number of trawls conducted allows some confidence in presence-absence and relative abundance comparisons.

Oceanographic measurements. Measurements of temperature, oxygen content, salinity and conductivity were made throughout the water column at all survey depths on each seasonal cruise using a Seabird CTD with a conducting cable. Oxygen measurements were made with a Clarke-type polarographic electrode. The accuracy of the probe was checked periodically by measuring the oxygen content of a water sample from a Niskin bottle attached to the CTD. Dissolved oxygen was determined by the Winkler method described previously in Vetter et al. (1994). In this study we present the full structure of the water column in terms of isotherms and oxypleths.

Tissue sampling. Tissue sampling procedures were performed as has been described previously (Vetter et al. 1994). Briefly, fish selected for biochemical analyses were immediately pulled from the catch and placed in a slush of partially frozen seawater. Blood samples were taken first and then samples of white muscle, heart and hiver were taken. White muscle samples were always taken from an area dorsal to the lateral line and behind the pectoral fin. Samples were quickly dissected then placed in a freeze-clamp, pre-cooled in liquid nitrogen to $-190^{\circ} \mathrm{C}$ and pressed at $100 \mathrm{~kg} \mathrm{~cm}-2$ (Vetter \& Hodson 1982). All samples were stored in liquid nitrogen for the duration of the cruise then transferred to a $-80^{\circ} \mathrm{C}$ freezer.

Enzyme analyses. White muscle samples were dissected from frozen tissue and homogenized in $10 \mathrm{mmol}$ $\mathrm{l}^{-1}$ Tris/HCl buffer, pH 7.2 at $20^{\circ} \mathrm{C}$. The homogenates were centrifuged at $1650 \times \mathrm{g}$ for $10 \mathrm{~min}$ at 0 to $4^{\circ} \mathrm{C}$. The supernatant portions were held on ice at 0 to $4^{\circ} \mathrm{C}$ and were used immediately for the measurement of enzyme activities. Assays were measured at $10 \pm 0.3^{\circ} \mathrm{C}$ in a Perkin-Elmer Lambda 3B UV/Visible spectrophotometer with data analysis software (Softways, Moreno Valley, CA). All assays were done in triplicate. Enzyme activities are expressed as $\mu \mathrm{mol}$ of substrate converted per minute per gram wet weight of tissue.

The activity of L-lactate dehydrogenase (LDH; EC 1.1.1.27; L-lactate: $\mathrm{NAD}^{+}$oxjdoreductase) was measured following the procedure of S. Kaupp (pers. comm.) as modified from Childress \& Somero (1979). The reaction was initiated by adding supernatant to $2.0 \mathrm{ml}$ of assay medium composed of $80 \mathrm{mmol}^{-1}$ Tris/ $\mathrm{HCl}$ buffer $\left(\mathrm{pH} 7.2\right.$ at $\left.20^{\circ} \mathrm{C}\right), 162 \mu \mathrm{mol} \mathrm{l}^{-1} \mathrm{NADH}$, $5 \mathrm{mmol} \mathrm{l}^{-1}$ sodium pyruvate, and $100 \mathrm{mmol} \mathrm{l}^{-1} \mathrm{KCl}$. The change in absorbance was measured at $340 \mathrm{~nm}$.

The activity of L-malate dehydrogenase $\left(\mathrm{MDH}_{\text {; }}\right.$ EC 1.1.1.37; L-malate: NAD + oxidoreductase) was assayed using the procedure of S. Kaupp (pers. comm.) also modified from Childress \& Somero (1979). The assay medium contained $40 \mathrm{mmol} \mathrm{l}^{-1}$ Tris/ $\mathrm{HCl}$, $40 \mathrm{mmol} \mathrm{l}^{-1} \mathrm{MgCl}_{2} \cdot 6 \mathrm{H}_{2} \mathrm{O}, 162 \mu \mathrm{mol} \mathrm{l^{-1 }} \mathrm{NADH}$, and $0.2 \mathrm{mmol} \mathrm{l}^{-1}$ oxaloacetate. The absorbance was monitored at $340 \mathrm{~nm}$ following the addition of supernatant to $2.0 \mathrm{ml}$ of the assay medium. 
The assay of citrate synthase [CS; EC 4.1.3.7; citrate oxaloacetate-lyase (CoA-acetylating)] activity followed the protocol of Childress \& Somero (1979) as modified by $\mathrm{S}$. Kaupp (pers. comm.). The assay medium contained $50 \mathrm{mmol} \mathrm{l}^{-1}$ imidazole/ $\mathrm{HCl}(\mathrm{pH} 8.0$ at $10^{\circ} \mathrm{C}$ ) $1.5 \mathrm{mmol} \mathrm{l}^{-1} \mathrm{MgCl}_{2}, 0.1 \mathrm{mmol} \mathrm{l}^{-1}$ 5,5-dithiobis(2-nitrobenzoic)acid (DTNB), $0.12 \mathrm{mmol}^{-1}$ acetylCoA, and $0.5 \mathrm{mmol}^{-1}$ oxaloacetate. Supermatant was added to $2.0 \mathrm{ml}$ of medium (minus oxaloacetate) and incubated at $10^{\circ} \mathrm{C}$ for $10 \mathrm{~min}$. This eliminated the need to subtract out a blank run. The reaction was initiated with the addition of oxaloacetate and the change in absorbance was observed at $412 \mathrm{~nm}$. In all cases the absorbance at $412 \mathrm{~nm}$ was constant prior to the addition of oxaloacetate.

Dry weight measurements. A frozen subsample of tissue $(0.4$ to $0.6 \mathrm{~g})$ for each fish was transferred to a preweighed microcentrifuge tube for determination of water content and dry weight of white muscle. These samples were placed into a concentration chamber (Speed Vac System SS2 by Savant Instruments Inc., Farmingdale, NY, USA) and dried to a constant weight Data are reported as percent water $\pm 1 \mathrm{SD}$

Statistical analyses. We tried to obtain a sufficiently wide size, depth, and oxygen range so that data sets could be analyzed by simple or stepwise multiple linear regressions that included weight, depth, and oxygen. The allometric relationships were described by the scaling coefficient $b$ in the equation $Y=a W^{b}$, where $Y$ is the enzyme activity, $a$ is a coefficient and $W$ is the wet weight. Simple linear regression analyses were performed on transformed data, so that the equations were of the form $\log ($ activity $)=\log (a)+b x$ $\log$ (wet $w t$ ). Environmental factors were then added for stepwise multiple regressions. The stepwise regression program that we used selected variables beginning with the most significant and added others if they increased the goodness of fit. Depth and environmental oxygen values were not log transformed. The relationship between \% waler in the white muscle and whole fish wet weight was computed as $\%$ water $=a+b \times$ wet $w t$. The regressions and analysis of variance (ANOVA) calculations were performed with the Minitab and Statview software packages.

Bioenergetic calculations. For purposes of ecological comparison and discussion we estimated the metabolic rates and food consumption rates of the 4 species studied in detail. The predicted CS activity for a $200 \mathrm{~g}$ individual was ad- justed from the $10^{\circ} \mathrm{C}$ assay conditions of this study to the $20^{\circ} \mathrm{C}$ conditions of Yang \& Somero (1993) by applying a $Q_{10}$ equation from Schmidt-Nielsen (1990) with a $Q_{10}=2$. The CS values were converted to weight-specific oxygen consumption via the regression equation in Yang \& Somero (1993) after correcting for a typographic error in the data $\left(\mu l \mathrm{O}_{2} \mathrm{~g}^{-1} \mathrm{~h}^{-1}\right.$ instead of $\mathrm{ml} \mathrm{O}_{2}$ $\mathrm{g}^{-1} \mathrm{~h}^{-1}$ ). Each data set was then converted from the $9^{\circ} \mathrm{C}$ conditions of Yang \& Somero (1993) to the habitat temperatures at different depths, again with a $Q_{10}$ of 2 . Then the mass-specific oxygen consumption rate was converted to the oxygen consumption rate of a $200 \mathrm{~g}$ fish. Oxygen consumption was converted to joules using the oxycalorific coefficient $19.4 \mathrm{~kJ} \mathrm{l}^{-1} \mathrm{O}_{2}$ (Jobling 1994). Metabolic rate in joules was used to estimate the food requirements of resting, non-reproductively active, $200 \mathrm{~g}$ individuals of the 4 species using the factor $0.2 \mathrm{~g} \mathrm{~kJ}^{-1}$ (Jobling 1994), a value that reflects the known diet of rockfishes and thornyheads (invertebrates and lipid-poor fishes)

\section{RESULTS}

\section{Habitat and bathymetric demography}

The temperature and oxygen contours were plotted on the depth profile of the study transect, a line $230^{\circ}$ SW from Santa Cruz, California, to a point $44 \mathrm{~km}$ from shore (Fig. 1). The oxygen minimum zone (OMZ;

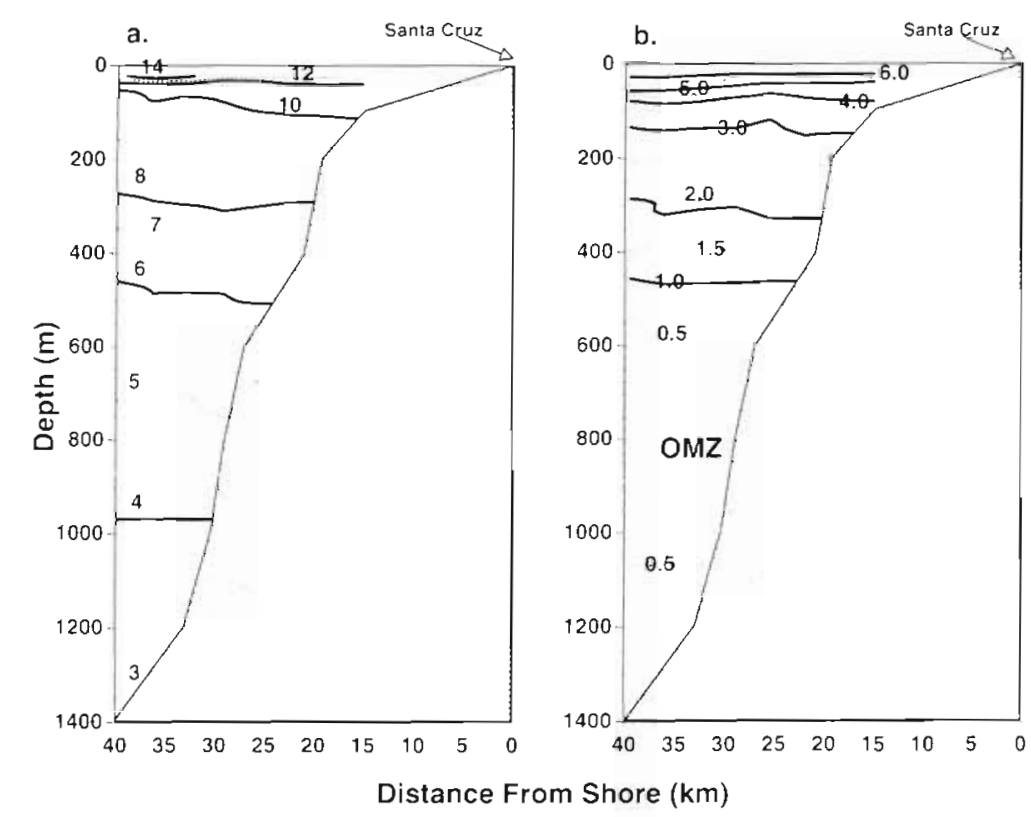

Fig. 1. (a) Temperature isotherms $\left({ }^{\circ} \mathrm{C}\right.$ ) and dissolved oxygen oxypleths (m) $\left.1^{-1}\right)$ in Monterey Bay, California, USA for the study site on the September 1991 cruise. Values are the means of 2 separate CTD casts. OMZ: oxygen minimum zone 


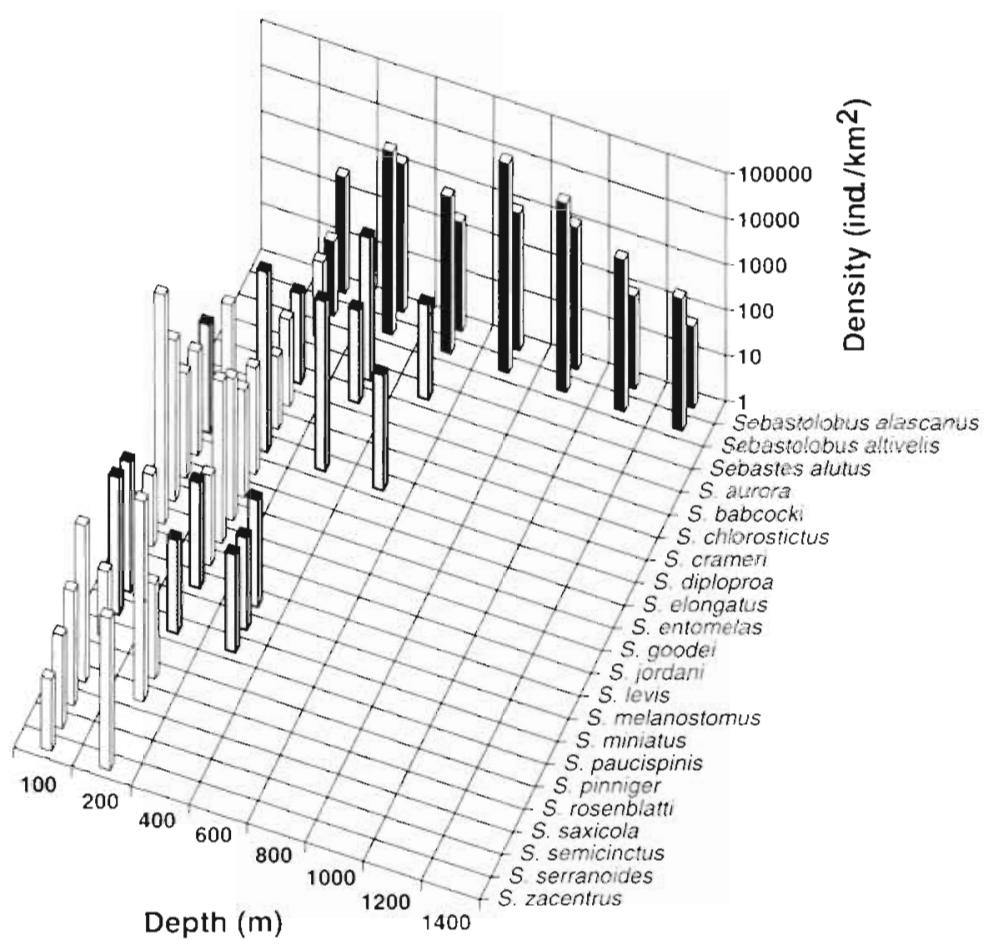

Fig. 2. Population densities of scorpaenld fishes along a depth transect of Monterey Bay. Black bars are the Sebastolobus species. Shaded bars are Sebastes species that extended below the shelf break. White bars are Sebastes species that are confined to the shelf in settlement of new recruits were observed, but no strong seasonal migration patterns of adult fishes were observed in this 1 yr study (data not shown). On the basis of their bathymetric distributions, 4 species were chosen for metabolic comparisons: Sebastes goodei, a shallow-living species with a narrow depth distribution (Fig. 3a); Sebastes diploproa, with a moderate depth distribution $(100$ to $600 \mathrm{~m}$ ) that included the shelf and the upper slope (Fig. 3b); Sebastolobus alascanus, with a wide size and depth range that included all depths sampled (Fig. 3c); and Sebastolobus altivelis, a deep-living specialist with a center of abundance in the OMZ (Fig. 3d).

For Sebastes goodei, S. diploprod, and Sebastolobus alascanus, the juveniles were confined to shallower water than the adults. Sebastolobus altivelis juveniles were found at all depths up to $1400 \mathrm{~m}$. $S$. alascanus attained much larger sizes than the other 3 species. S. alascanus adults prefered the same depth strata as $S$. altivelis adults but there was little overlap in size distributions of the 2 species. Catches of both Sebastolobus species were low at $600 \mathrm{~m}$.

The relationships between fork length and wet weight were calculated for all 4 of the species selected for biochemical studies: Sebastes goodei, $\log (\mathrm{w} t)=$ $-5.11+3.1 \times \log$ (length) $\left(\mathrm{n}=38, \mathrm{R}^{2}=0.996\right) ;$ Sebastes diploproa, $\log (\mathrm{w} t)=-5.69+3.38 \times \log$ (length) $(\mathrm{n}=41$, $\left.\mathrm{R}^{2}=0.990\right)$; Sebastolobus alascanus, $\log (\mathrm{wt})=-5.51+$ $3.24 \times \log ($ length $) \quad\left(\mathrm{n}=141, \mathrm{R}^{2}=0.996\right) ;$ and Sebastolobus altivelis, $\log (w t)=-5.44+3.23 \times \log$ (length) $\left(n=38, R^{2}=0.986\right)$. There were no significant differences between sexes.

\section{Metabolic size scaling and differences between \\ species}

much wider bathymetric distributions (200 to $1400 \mathrm{~m}$ ) and were the only scor-paenids extending into and beyond the OMZ. Sebastolobus altivelis had a clear peak of abundance at $800 \mathrm{~m}$ (Table 1), but Sebastolobus alascanus had a much broader abundance distribution (Table 1, Fig. 2)

There was a trend of increasing weight with increasing depth (Table 1; Vetter unpubl. data). In most species the increase was small but in Sebastolobus alascanus mean body weight increased roughly 5 -fold from 200 to $1400 \mathrm{~m}$ (Table 1).

The length composition and density of each species at all depths for the 3 cruises was plotted and examined for seasonal trends in abundance. Apparent seasonal pulses
Size-scaling relationships and inter-specific comparisons were examined by simple linear regressions of log-transformed enzyme activities versus log weight (Table 2, first entry for each enzyme, and Figs, 4 to 6). Since both slopes and intercepts differed between species, we chose $200 \mathrm{~g}$ (a weight common to all species). as a basis for inter-specific comparisons (Table 2, last column). Where weight was not significant (slopes not significantly different from zero, $p \geq 0.05$ ), we computed the mean and used that for comparison at $200 \mathrm{~g}$. We also split the Sebastolobus spp. data sets into juveniles $(\leq 10 \%$ sexually mature), maturing $(10$ to $90 \%$ 
Table 1. Mean fork length, weight, density and sample size of fish collected from difterent depths in Monterey Bay. Length is grand mean of mean lengths tor each positive haul \pm SD of differences between hauls. Mean fish weight was calculated in 2 ways, mean weight as grand mean of weights of fish in each haul/total number and as mean wt by haul/number \pm SD of differences between hauls. Density is catch/total swept area tor all hauls as ind. $\mathrm{km}^{-2}$. A positive haul is one where at least 1 individual of that species was captured

\begin{tabular}{|c|c|c|c|c|c|c|c|c|}
\hline \multirow[t]{2}{*}{ Species } & \multirow[t]{2}{*}{ Depth $\{m\}$} & \multirow{2}{*}{$\begin{array}{l}\text { Length } \pm S D \\
(\mathrm{~mm})\end{array}$} & \multirow{2}{*}{$\begin{array}{l}\text { Weight (g) } \\
\text { (total wh) } \\
\text { total no.) }\end{array}$} & \multirow{2}{*}{$\begin{array}{c}\text { Weight } \pm \text { SD }(g) \\
\text { (mean wt by } \\
\text { trawl/no.) }\end{array}$} & \multirow{2}{*}{$\begin{array}{l}\text { Density } \\
\text { (ind. } \\
\mathrm{km}^{-2} \text { ) }\end{array}$} & \multirow{2}{*}{$\begin{array}{l}\text { Catch } \\
\text { (no. of } \\
\text { ind.) }\end{array}$} & \multicolumn{2}{|c|}{ Hauls } \\
\hline & & & & & & & Total & Positive \\
\hline \multirow{7}{*}{ Sebastolobus alascanus } & 200 & $254 \pm 70$ & 242 & $306 \pm 200$ & 348 & 48 & 7 & 6 \\
\hline & 400 & $286 \pm 81$ & 361 & $405 \pm 175$ & 1783 & 308 & 7 & 7 \\
\hline & 600 & $276 \pm 79$ & 307 & $398 \pm 143$ & 246 & 38 & 7 & 6 \\
\hline & 800 & $367 \pm 68$ & 696 & $670 \pm 155$ & 1031 & 370 & 8 & 8 \\
\hline & 1000 & $470 \pm 80$ & 1596 & $1547 \pm 163$ & 1326 & 392 & 7 & 7 \\
\hline & 1200 & $506 \pm 63$ & 1886 & $2009 \pm 665$ & 108 & 38 & 8 & 8 \\
\hline & 1400 & $454 \pm 29$ & 1043 & 1304 & 62 & 5 & 7 & 2 \\
\hline \multirow{7}{*}{ Sebastolobus altivelis } & 200 & $170 \pm 99$ & 91 & $91 \pm 64$ & 43 & 2 & 7 & 2 \\
\hline & 400 & $184 \pm 32$ & 84 & $88 \pm 15$ & 10164 & 1680 & 7 & 7 \\
\hline & 600 & $178 \pm 37$ & 77 & $88 \pm 29$ & 2764 & 507 & 7 & 7 \\
\hline & 800 & $182 \pm 38$ & 77 & $75 \pm 25$ & 38962 & 13988 & 8 & 8 \\
\hline & 1000 & $215 \pm 51$ & 137 & $133 \pm 21$ & 13419 & 4009 & 7 & 7 \\
\hline & 1200 & $207 \pm 43$ & 119 & $115 \pm 14$ & 2130 & 743 & 8 & 8 \\
\hline & 1400 & $217 \pm 40$ & 136 & $136 \pm 15$ & 788 & 87 & 7 & 3 \\
\hline Sebastes alutus & 200 & 240 & 91 & 91 & 47 & 1 & 7 & 1 \\
\hline \multirow[t]{2}{*}{ Sebastes aurora } & 400 & $278 \pm 32$ & 353 & $371 \pm 52$ & 1356 & 218 & 7 & 7 \\
\hline & 600 & $323 \pm 21$ & 544 & 544 & 119 & 3 & 7 & 1 \\
\hline \multirow[t]{2}{*}{ Sebastes babcockl } & 200 & $185 \pm 7$ & 91 & 91 & 95 & 2 & 7 & 1 \\
\hline & 400 & $368 \pm 102$ & 980 & $1094 \pm 624$ & 108 & 10 & 7 & 4 \\
\hline \multirow[t]{2}{*}{ Sebastes chlorostictus } & 100 & $285 \pm 70$ & 454 & 454 & 63 & 2 & 7 & 2 \\
\hline & 200 & $263 \pm 66$ & 307 & $391 \pm 352$ & 79 & 9 & 7 & 4 \\
\hline Sebastes crameri & 200 & 210 & 91 & 91 & 38 & 1 & 7 & 1 \\
\hline \multirow[t]{4}{*}{ Sebastes diploproa } & 100 & $192 \pm 38$ & 91 & 91 & 231 & 6 & 7 & 1 \\
\hline & 200 & $160 \pm 58$ & 119 & $102 \pm 75$ & 8662 & 1413 & 7 & 7 \\
\hline & 400 & $283 \pm 26$ & 407 & $380 \pm 62$ & 5144 & 769 & 7 & 6 \\
\hline & 600 & $298 \pm 25$ & 442 & $441 \pm 4$ & 327 & 16 & 7 & 2 \\
\hline \multirow[t]{2}{*}{ Sebastes elongatus } & 100 & $223 \pm 34$ & 145 & $153 \pm 49$ & 182 & 21 & 7 & 4 \\
\hline & 200 & $232 \pm 34$ & 174 & $163 \pm 62$ & 209 & 37 & 7 & 7 \\
\hline \multirow[t]{2}{*}{ Sebastes entomelas } & 100 & $342 \pm 23$ & 572 & 572 & 192 & 5 & 7 & 1 \\
\hline & 200 & $331 \pm 23$ & 523 & $580 \pm 126$ & 214 & 17 & 7 & 3 \\
\hline \multirow[t]{2}{*}{ Sebastes goodei } & 100 & $169 \pm 62$ & 159 & $103 \pm 111$ & 3212 & 592 & 7 & 6 \\
\hline & 200 & $296 \pm 41$ & 366 & $364 \pm 201$ & 1197 & 219 & 7 & 7 \\
\hline \multirow{2}{*}{ Sebastes jordani } & 100 & $142 \pm 13$ & 40 & $29 \pm 25$ & 138981 & 22095 & 7 & 5 \\
\hline & 200 & $223 \pm 32$ & 112 & $97 \pm 28$ & 3294 & 537 & 7 & 6 \\
\hline Sebastes levis & 100 & $290 \pm 156$ & 522 & $522 \pm 609$ & 36 & 2 & 7 & 2 \\
\hline & 200 & $382+42$ & 900 & $985 \pm 329$ & 92 & 6 & 7 & 3 \\
\hline Sebastes melanostomus & 200 & 320 & 454 & 454 & 37 & 1 & 7 & 1 \\
\hline & 400 & $357 \pm 78$ & 835 & $791 \pm 271$ & 221 & 31 & 7 & 6 \\
\hline Sebastes miniatus & 100 & $421 \pm 32$ & 1188 & 1488 & 687 & 25 & 7 & 1 \\
\hline & 400 & $463 \pm 15$ & 1436 & 1436 & 105 & 3 & 7 & 1 \\
\hline Sebastes paucispinis & 100 & $246 \pm 164$ & 499 & $591 \pm 617$ & 989 & 179 & 7 & 6 \\
\hline & 200 & $441 \pm 61$ & 1076 & $1052 \pm 473$ & 112 & 14 & 7 & 5 \\
\hline & 400 & $480 \pm 80$ & 1417 & 1417 & 140 & 4 & 7 & 1 \\
\hline Sebastes pinniger & 100 & 250 & 272 & 272 & 27 & 1 & 7 & 1. \\
\hline Sebastes rosenblatti & 200 & $214 \pm 44$ & 82 & $83 \pm 11$ & 119 & 5 & 7 & 2 \\
\hline Sebastes saxicola & 100 & $133 \pm 15$ & 33 & $38 \pm 7$ & 2699 & 355 & 7 & 5 \\
\hline & 200 & $167 \pm 26$ & 80 & $70+12$ & 23608 & 3682 & 7 & 7 \\
\hline Sebastes semicinctus & 100 & $116 \pm 15$ & 10 & 10 & 316 & 9 & 7 & 1 \\
\hline Sebastes serranoides & 100 & $420 \pm 46$ & 1134 & 1134 & 104 & 3 & 7 & 1 \\
\hline Sebastes zacentrus & 100 & 130 & 45 & 45 & 36 & 1. & 7 & 1 \\
\hline & 200 & $215 \pm 37$ & 159 & $131 \pm 59$ & 2072 & 339 & 7 & 7 \\
\hline
\end{tabular}


a. Sebastes goodei (chilipepper rockfish)

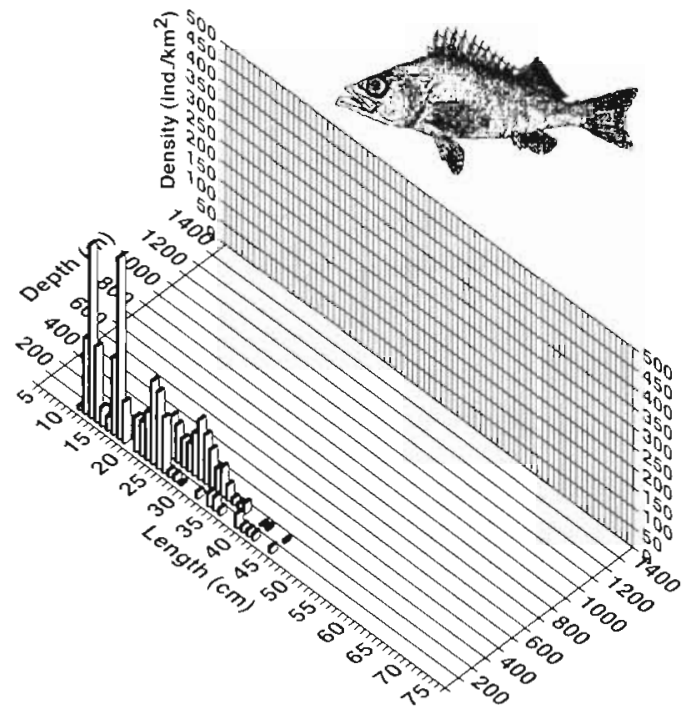

c. Sebastolobus alascanus (shortspine thornyhead)

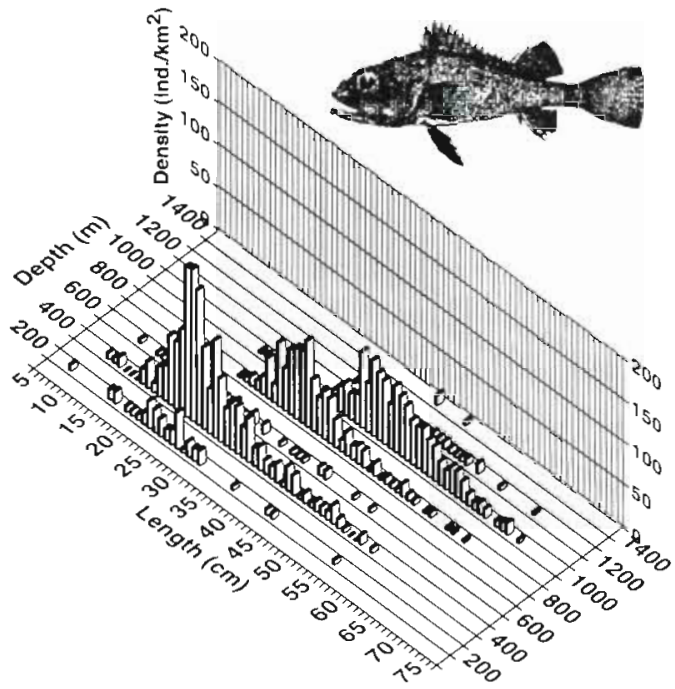

b. Sebastes diploproa (splitnose rockfish)

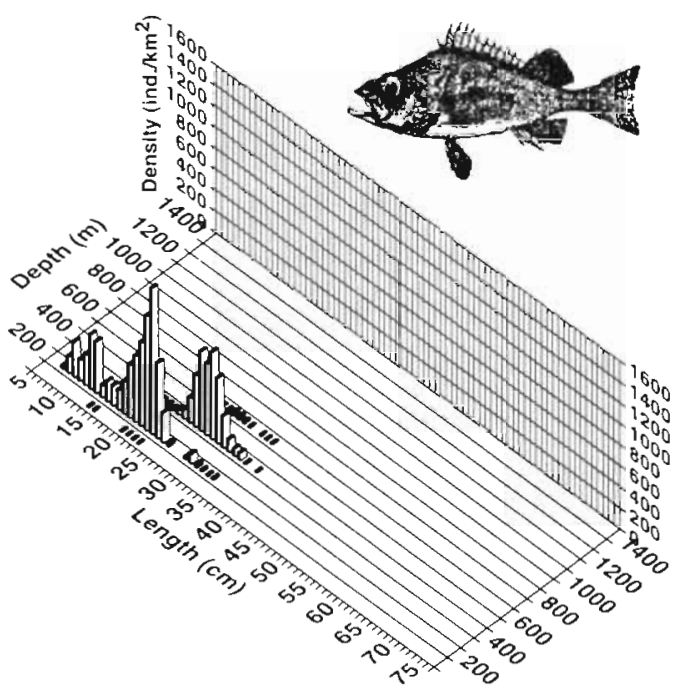

d. Sebastolobus altivelis (longspine thornyhead)

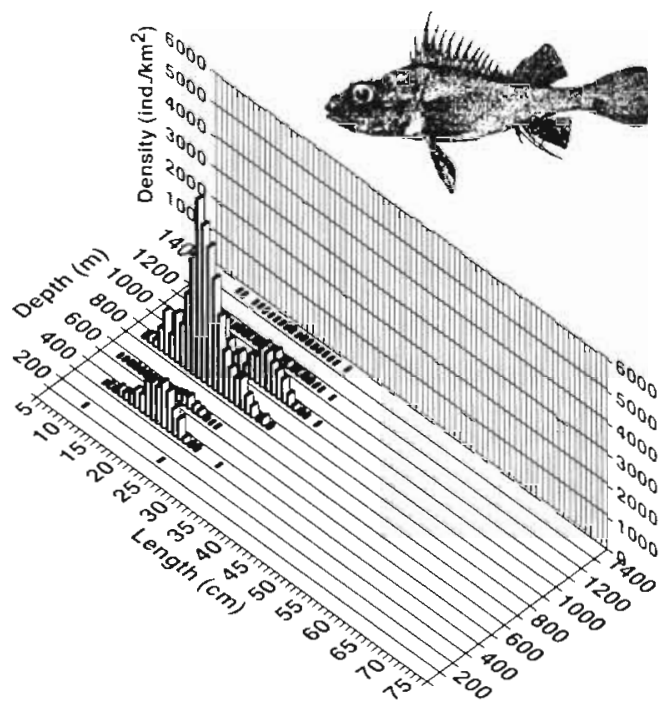

Fig. 3. Length composition and population density of 4 scorpaenid species along a depth transect in Monterey Bay. (a) Sebastes goodei. (b) Sebastes diploproa. (c) Sebastolobusalascanus, (d) Sebastolobus altivels mature), and adults ( $\geq 90 \%$ mature) based on the maturity curves of Ianelli et al. (1994) and our length-weight regressions. Ranking the 4 species according to the typical depths of occurrence of a $200 \mathrm{~g}$ specimen, they showed a decrease in mean activity for the 3 enzyme activities as a function of depth of occurrence (Table 2).

LDH activity in the active, shallow-living Sebastes goodei scaled positively with weight $(b=0.11$; Table 2 , Fig. 4a). S. diploproa (Fig 4 b) and Sebastolobus alascanus (Fig. $4 \mathrm{c}$ ) did not show scaling of LDH with size for the entire size range. The deep water specialist Sebastolobus altivelis scaled negatively for $\operatorname{LDH}(b=-0.28$; Table 2, Fig. 4). In juvenile $S$. alascanus, comparable to those examined by Siebenaller \& Somero (1982), the scaling relationship was positive. Adult $S$. alascanus scaled significantly negative with weight $(b=-0.131 ; \mathrm{p}=$ 0.05; data not shown), but oxygen was a slightly better predictor of LDH activity for this size class (Table 2). The linear regression for $\mathrm{LDH}$ versus weight in $S$. altivelis was highly significant (Table 2, Fig. 4d) but other environmental factors were also clearly important (see below). Activity of MDH did not change with body weight in either $S$. goodei or $S$. diploproa, but it scaled negatively with weight in $S$. alascanus $(b=-0.12)$. The coefficient was strongly negative in $S$. altivelis $(b=-0.32$; Fig. 5). CS activity decreased with increasing body size in all 4 species. The scaling was not significant for $S$. diploproa. S. goodei had a coefficient of $b=-0.15$. S alascanus had $b=-0.23$ and $S$. altivelis was the most negative at $b=-0.46$ (Fig. 5 ). 


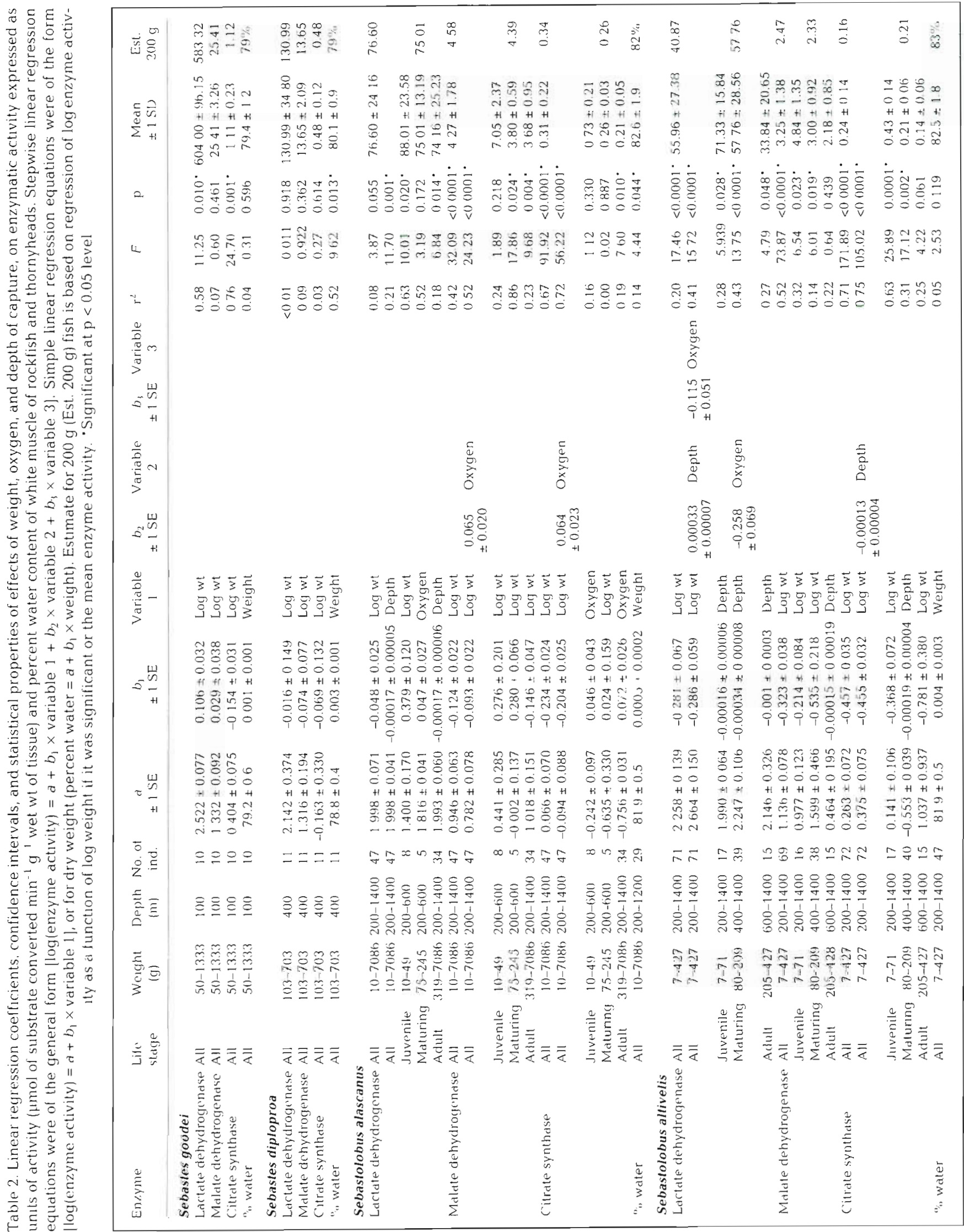




\section{Depth- and oxygen-related differences in metabolic activity}

The effects of depth and oxygen on intra-specific enzyme activities were examined by stepwise linear regressions that included weight, depth, and oxygen (Table 2). Variables were included by order of significance with non-significant variables omitted. There was not a large enough range of depths or oxygen concentrations to explore these relationships in the 2 Sebastes species, but there was for the 2 Sebastolobus species. After we had carried out our basic enzyme studies, we went back and analyzed more of the maturing Sebastolobus altivelis $(80$ to $209 \mathrm{~g}, \mathrm{n}=40$ ) because this was the group for which we had the greatest number of similar sized individuals at the greatest range of depths. We also examined the adult Sebastolobus alascanus in more detail because of the large sample size ( $\geq 319 \mathrm{~g}, \mathrm{n}=34)$. We found significant effects of depth and oxygen in some cases. Depth was the most significant predictor of LDH activity in both adult $S$. alascanus and maturing $S$. altivelis. Oxygen concentrations were also significant for predicting $\mathrm{LDH}$ levels in $S$. altivelis (Table 2). The addition of oxygen to the regression improved the fit for $S$. alas-

canus $\mathrm{MDH}$, but not for $\mathrm{S}$. altivelis $\mathrm{MDH}$. Oxygen was the most significant predictor of CS activity in adult $S$. alascanus but depth was most significant for maturing $S$. altivelis. The most complete data set, that for maturing $S$. altivelis, was also examined for depth effects by ANOVA. We plotted the means and standard deviations of enzyme activities for all depths (Fig. 7) For all 3 enzymes the $600 \mathrm{~m}$ depth contour contained the highest enzyme activities. Depths that were significantly different from the $600 \mathrm{~m}$ value based on Tukey's test at the $\mathrm{p} \leq$ 0.05 level are marked with an asterisk (Fig. 7).

\section{DISCUSSION}

This is the first enzyme study of the deep-water scorpaenids that incorporates the complete size and depth distributions of the demersal populations of the species considered. It is also the first study to segregate and compare individuals on the basis of their depth of capture. Submersible observations, tag re- capture data, and bathymetric demography (summarized in Jacobson \& Vetter 1996) indicate that with the exception of Sebastes goodei, individuals are sedentary and likely to remain at a particular depth for extended periods of time.

The first interest shown in the physiology and biochemistry of Sebastolobus alascanus and $S$. altivelis was as a model system for comparative studies of depth adaptation that met 4 criteria: (1) phylogenetically close, (2) similar life history, (3) encounter similar thermal regimes, (4) exhibit different depth distributions (Siebenaller \& Somero 1978). While that study and subsequent studies have produced numerous biochemical insights into depth adaptation (summarized in Siebenaller \& Somero 1989), they are not very useful for understanding the bioenergetics of natural communities because the size and depth distributions of the specimens analyzed were not well documented. It is now clear from the present study and other recent work (Wakefield 1990, Jacobson \& Vetter 1996) that $S$. alascanus: (1) attains an order of magnitude larger 


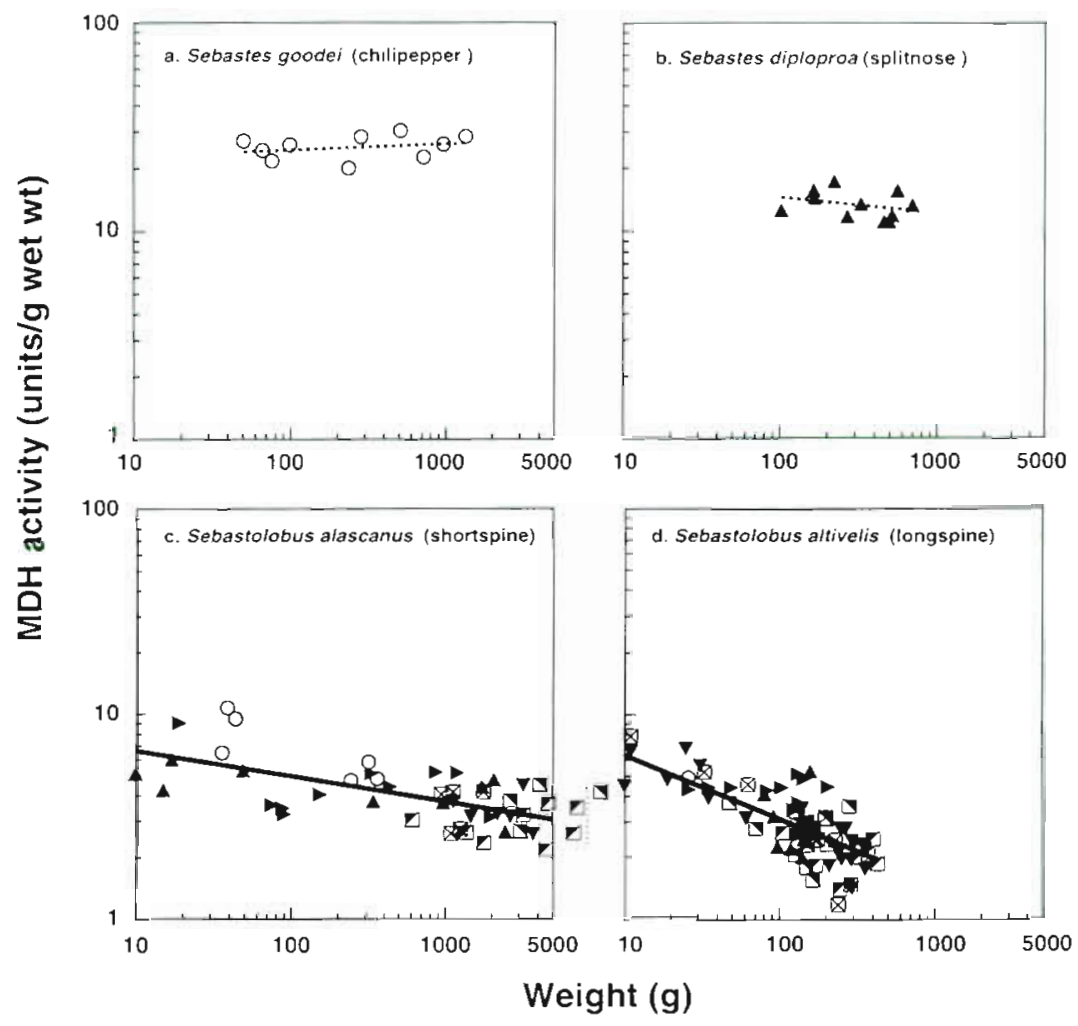

Fig. 5. Sebastes goodei, Sebastes diploproa, Sebastolobus alascanus, Sebastolobus altivelis. As Fig. 4, except for malate dehydrogenase (MDH) activity

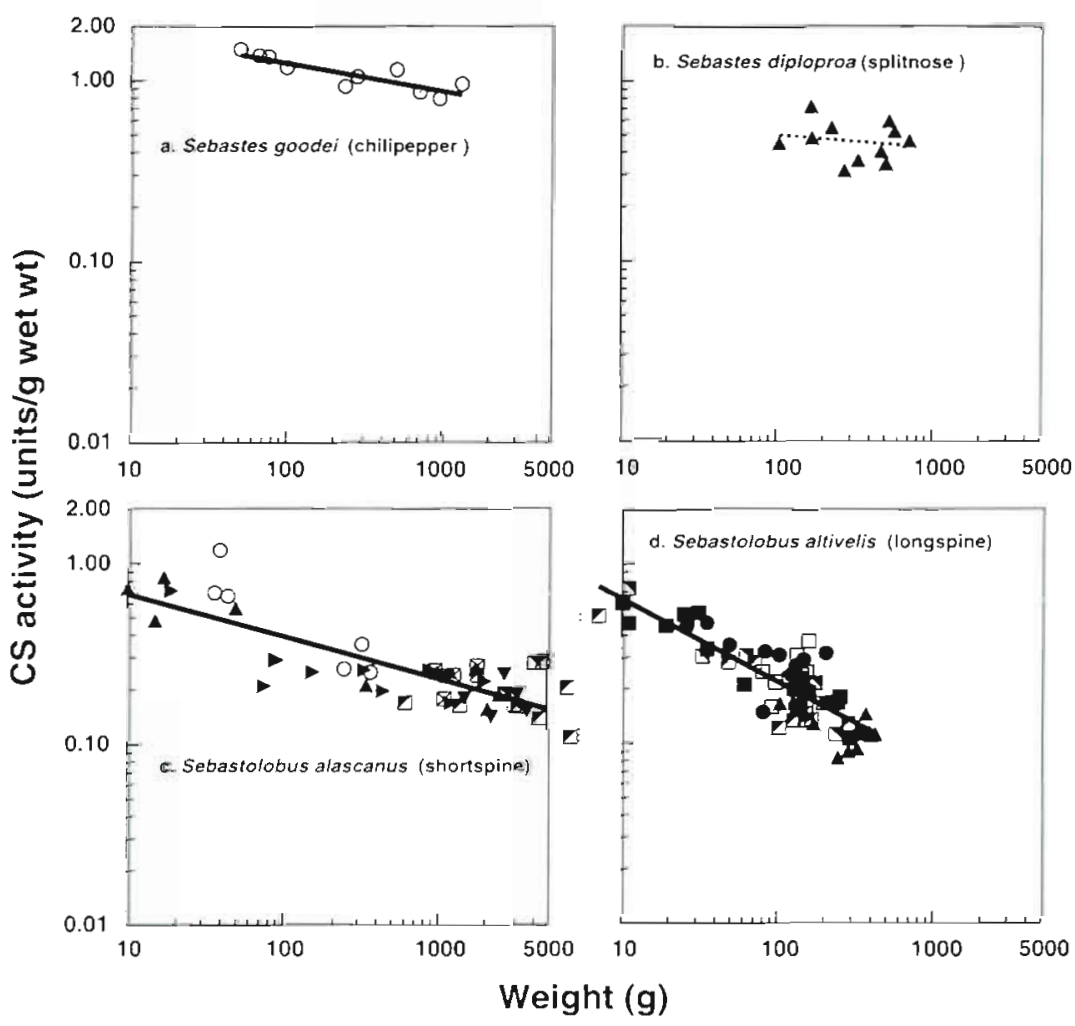

Fig. 6. Sebastes goodei, Sebastes diploproa, Sebastolobus alascanus, Sebastolobus altivelis. As Fig. 4, except for citrate synthase (CS) activity body size than $S$. altivelis throughout its geographic range (Fig $3 ;$ and Jacobson \& Vetter 1996); (2) as an adult, occupies similar depths as $S$. altivelis, but is displaced by size when co-inhabiting deep water (Fig. 3; and Wakefield 1990, Jacobson \& Vetter 1996); and (3) remains more metabolically active than $S$. altivelis throughout its life, regardless of depth of capture (Figs. 4, 5 \& 6). It is also clear that $S$ alascanus ontogenetically migrates from shallow to deep water after settlement, while $S$. altivelis does not (Fig. 3). In effect, previous researchers have compared juvenile (shallow) $S$. alascanus to mixed age (deep) populations of $S$. altivelis. In this study we also examined depth-specific differences in intra-specific metabolism, and the possible influence of the the OMZ on the distribution and bioenergetics of the rockfish-thornyhead community. First we will review the bathymetric demography, then the enzymatic comparisons. Finally, we will use the enzyme data to make predictions regarding the bioenergetics of the 4 species compared.

\section{Bathymetric distributions}

The species diversity of scorpaenids on the shelf is in stark contrast to that of the upper slope habitat (Fig. 2). The 22 species (Sebastes and Sebastolobus) encountered on the shelf in this survey include only those trawl-susceptible species associated with softbottom benthic habitats. Many more rockfish species inhabitat rocky bottom. pelagic, and kelp habitats in Monterey Bay. Six Sebastes species were found on the upper slope at $400 \mathrm{~m}$ and only 2 were present at $600 \mathrm{~m}$. Lower food availability probably limits the extent to which species can partition food resources, limiting the number of species that can colonize the slope habitat. No Sebastes species entered the $\mathrm{OMZ}$

In Sebastes goodei. S. diploproa and especially Sebastolobus alascanus, larger individuals tended to occur in 


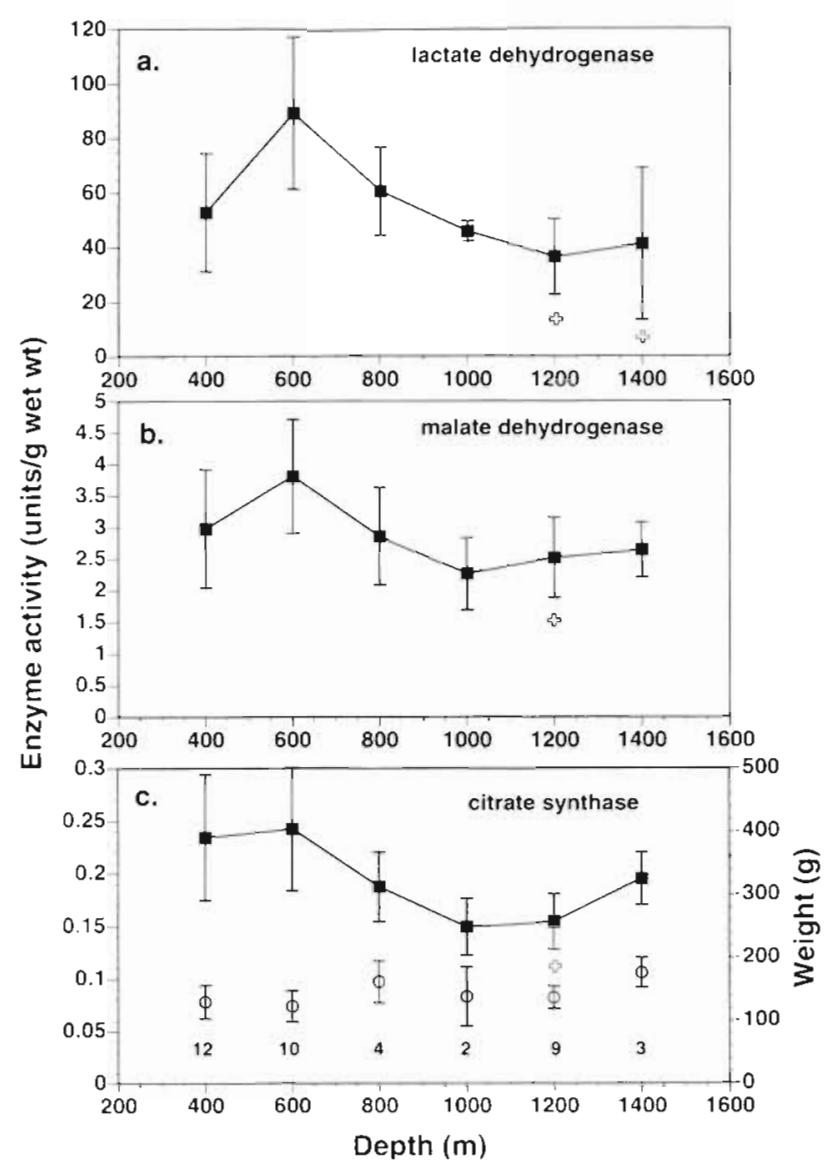

Fig. 7. Sebastolobus altivelis. Changes in mean enzyme activtty ( $\mathbf{})$ with depth in similar-sized maturing stage individuals (80 to $209 \mathrm{~g}$ ). Error bars are \pm 1 SD, Numbers shown $\mathrm{in}$ bottom plot are numbers of fish at each depth. (O) Mean weights of the fish at each depth. (ઐ) Depths that were significantly different from the activity at $600 \mathrm{~m}$

deeper water. Sebastolobus altivelis had a conical distribution centered at $800 \mathrm{~m}$, and the smallest size classes were present from 200 to $1400 \mathrm{~m}$. Throughout their bathymetric distribution, $S$. alascanus and $S$. altivelis are separated by size. At 800 to $1400 \mathrm{~m} \mathrm{~S}$. alascanus is most likely a predator on, rather than a competitor with, S. altivelis (see discussion in Jacobson \& Vetter 1996). The densities of both Sebastolobus species and perhaps $S$. diploproa were depressed at $600 \mathrm{~m}$. This depression in numbers was not apparent in flatfish from this same site (Vetter et al. 1994), suggesting that fishing pressure is not the explanation.

\section{Enzymatic comparisons}

Specific hypotheses regarding the metabolic responses of the 4 most thoroughly studied species (Fig. 3) to different habitat variables were examined in the light of our enzyme data. The metabolic activity of a population of fish can be influenced by a range of inherited and environmental factors. In this study we examined 4 factors: (1) the mean metabolic set points of the species as determined by their normal activity patterns, (2) allometric scaling with growth, (3) state of sexual maturity, and (4) environmental effects of depth and oxygen content at the location of capture. Depth includes several hidden variables, including temperature, light level, food availability and hydrostatic pressure. All of the above factors can give insights into the evolutionary and environmental conditions that shape metabolic activity. In fish, aerobic metabolic activity is thought to scale negatively with size due to: (1) economies in the cost of transport with increasing body size, (2) increased blood circulation time with increasing size, and (3) the concomitant decreased rate of oxygen delivery to aerobic tissue (reviewed by Goolish 1991, 1995). Anaerobic burst activity, as reflected in LDH activity, is thought to scale positively, reflecting the proportionally greater locomotive drag associated with accelerating a larger object (Somero \& Childress 1980). In addition it has been suggested that the degree of positive scaling is greater in active species that rely on burst swimming than for sedentary species (Somero \& Childress 1990). Although this may be true under optimal conditions, LDH is also very sensitive to changes in nutritional condition and varies greatly during experimental food limitation in several slope species including Sebastolobus alascanus (Yang \& Somero 1993), Dover sole Microstomus pacificus (Vetter et al. 1994), and sable fish Anoplopoma fimbria (Sullivan \& Somero 1983). LDH might also be sensitive to environmental oxygen levels and the likelihood of experiencing anaerobic conditions.

The species studied here exhibited a range of responses in LDH activity. The mean activity of equal sized fishes decreased with average depth of occurrence of the 4 species. This is consistent with previous studies of metabolism and depth in fishes (reviewed by Childress 1995). The metabolically active shelf inhabitant Sebastes goodei scaled positively with increasing body size. There was no significant scaling relationship in the deeper-living S. diploproa. The scaling in Sebastolobus alascanus was complex and reflected the consequences of ontogenetic migration to deep water. Shallower-living juvenile S. alascanus scaled positively, while adults scaled negatively, presumably reflecting lower activity and growth in the deep-living adult population (Table 2, Fig. 4c, d). Siebenaller \& Somero (1982) reported positive scaling for LDH in both of the Sebastolobus species studied here, but their study examined only small fish $(<250 \mathrm{~g})$. Complex patterns of scaling of LDH with body weight (shallow-living juveniles scaling up, deeper-living adults scaling down), 
were also observed in the Dover sole, also an ontogenetic migrator of the slope community (Vetter et al. 1994). The deep-living, non-migrating Sebastolobus altivelis scaled consistently negatively. The change in slope from positive to negative between the 4 species is consistent with the idea that deep-living species with lowered burst swimming capacity show lessened or even negative scaling with body weight. However, there are clearly other factors influencing the metabolic activity of deep-living fishes and this is reflected in the depth and oxygen related changes discussed below.

MDH scaled positively in Sebastes goodei, no scaling was apparent in $S$. diploproa, and increasingly negative scaling was observed in Sebastolobus alascanus and Sebastolobus altivelis. MDH activity patterns reflect the role of $\mathrm{MDH}$ in both aerobic energy production and biosynthetic pathways. The mean levels of activity for the 4 species reflected the decrease in overall activity for the deeper-living species.

CS activity scaled negatively for all species but the slope was most negative for Sebastolobus altivelis (Fig. 6. Table 2). Negative scaling coefficients were not as large as in the flatfish (Vetter et al. 1994). A partial explanation for this, and an interesting difference between the scorpaenids and the flatfish, is that the scorpaenids exhibited little to no intra-specific changes in water content associated with changes in metabolic enzyme activity (Table 2 ), and the range (Sebastolobus goodei $79 \%$ to $S$. altivelis $83 \%$ ) in water content between the 4 species was also small.

Because of the common pattern of ontogenetic migration in slope species, it is very difficult to find a species with similar-sized individuals occurring at a wide variety of depths. We took advantage of this in Sebastolobus altivelis and ran a large number of individuals in the maturing size class ( $n=40$; Table 2 , Fig. 7). There were significant differences between depths, but they do not appear to be due to just low oxygen since the highest and lowest values were encompassed by the OMZ. Furthermore, all 3 metabolic enzymes varied in a similar manner, rather than LDH rising and CS falling in response to the low oxygen conditions of the OMZ. This suggests that the metabolic differences at each depth are due to changes in nutritional condition rather than changes in anderobic poise (Yang \& Somero 1993). The peak in metabolic activity (Fig. 7) coincides with the decrease in fish density at $600 \mathrm{~m}$ (see Fig 9) and would suggest more food resources per individual. The reasons for low abundances at $600 \mathrm{~m}$ are not clear but could be due to predation (perhaps by elephant seal). It is unlikely to be due to trawling activity because other species including the flatfishes (Vetter et al. 1994) did not show a dip in densities at $600 \mathrm{~m}$. Laboratory studies support the conclusion that LDH levels in particular vary with food intake in Sebastolobus spp. Yang \& Somero (1993) measured freshly caught $S$. alascanus and compared them to fish maintained without food and those fed ad libitum. After about $3 \mathrm{mo}$, the fasted group were the same as the field-caught fish, while those allowed to feed showed about a $200 \%$ increase in LDH levels when compared with fasted or fieldcaught fish. Depth-specific covariant differences in the 3 white muscle enzyme activities were also observed in Dover sole (Vetter et al. 1994). For Dover sole the largest metabolic depression occurred when fish migrated from the shelf to the slope habitat. Here again laboratory studies demonstrated that increased ration positively affected LDH levels. Similar individual variations in enzyme activity have been seen in more mobile, epibenthic species such as the sablefish Anoplopoma fimbria and cod Gadus morhua when comparing different geographic regions and seasons (Sullivan \& Somero 1983, Pelletier et al. 1993). In all of these studies fine-scale differences in habitat quality with depth (as reflected in metabolic enzyme activities) could not be explained by any one physical variable such as oxygen, temperature, or hydrostatic pressure. Rather, metabolic condition appears to be a function of the interaction of various biotic and physical factors, both measured and unmeasured, that lead to differences in habitat quality

\section{Bioenergetic comparisons}

Yang \& Somero (1993) showed that white muscle CS activity was an excellent indicator of oxygen consumption rate in Sebastolobus alascanus and Scorpaena guttata. Moreover, the scaling relationship for CS activity versus oxygen consumption was the same for both species. This allows us to predict metabolic rates for the 4 most thoroughly studied scorpaenid species (Fig. 3) at the environmental conditions of their respective habitats. When the CS activities of these 4 scorpaenids are converted to oxygen consumption rates, or energy consumption rates, and adjusted to the conditions of their respective habitat depths, it is possible to compare the bioenergetic demands and feeding requirements of same-sized individuals under different environmental conditions (Table 3, Fig. 8). By including density and mean size information (Table 1), it is also possible to compare population level properties such as the relative maintenance energy requirements of the 2 co-occurring Sebastolobus populations at each depth (Table 3, Fig. 9), and to compare them with previous estimates from the Santa Catalina basin (Smith \& Brown 1983).

The steps in the calculation are shown in Table 3. First CS activity for a $200 \mathrm{~g}$ individual was obtained 


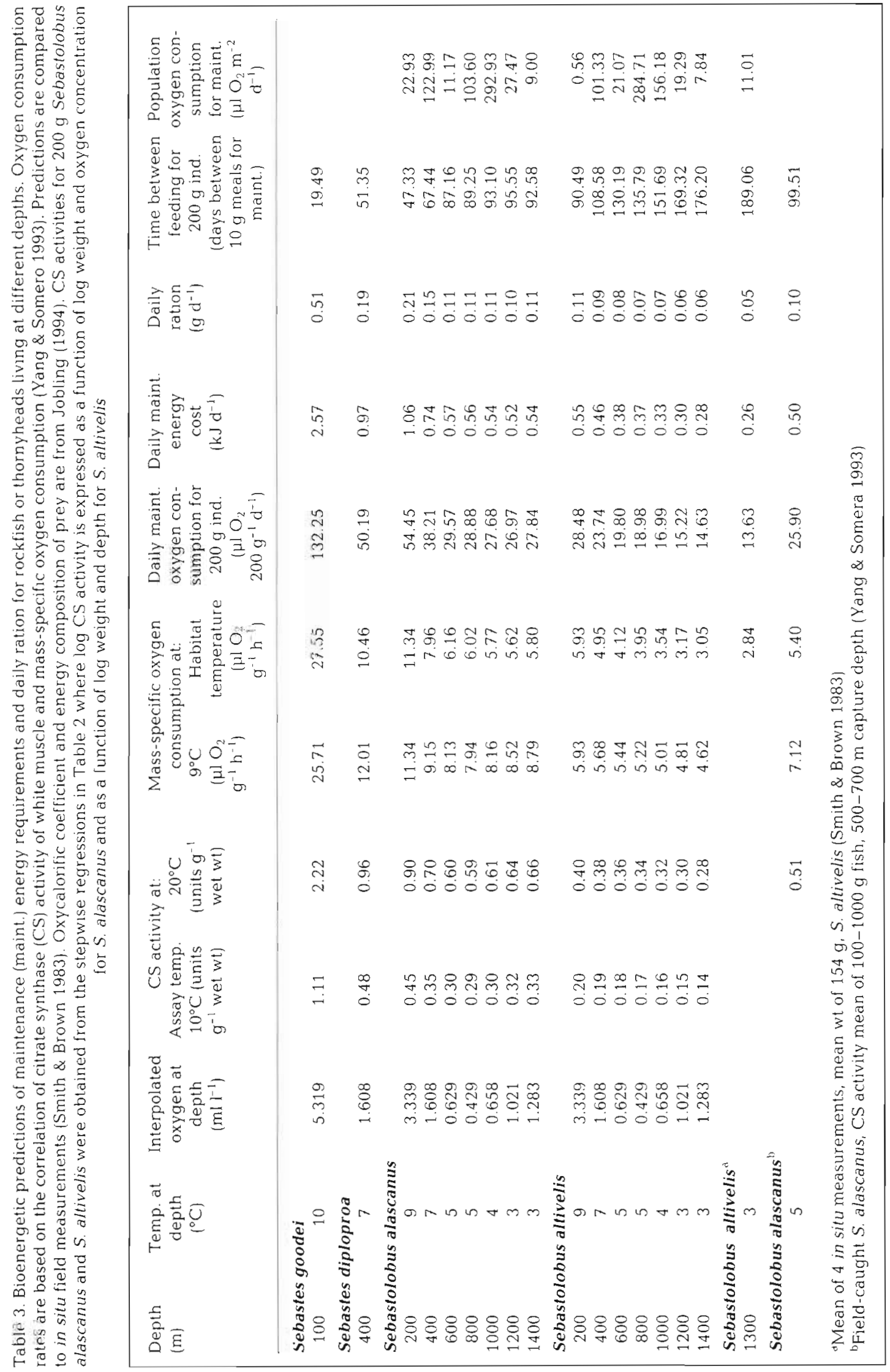




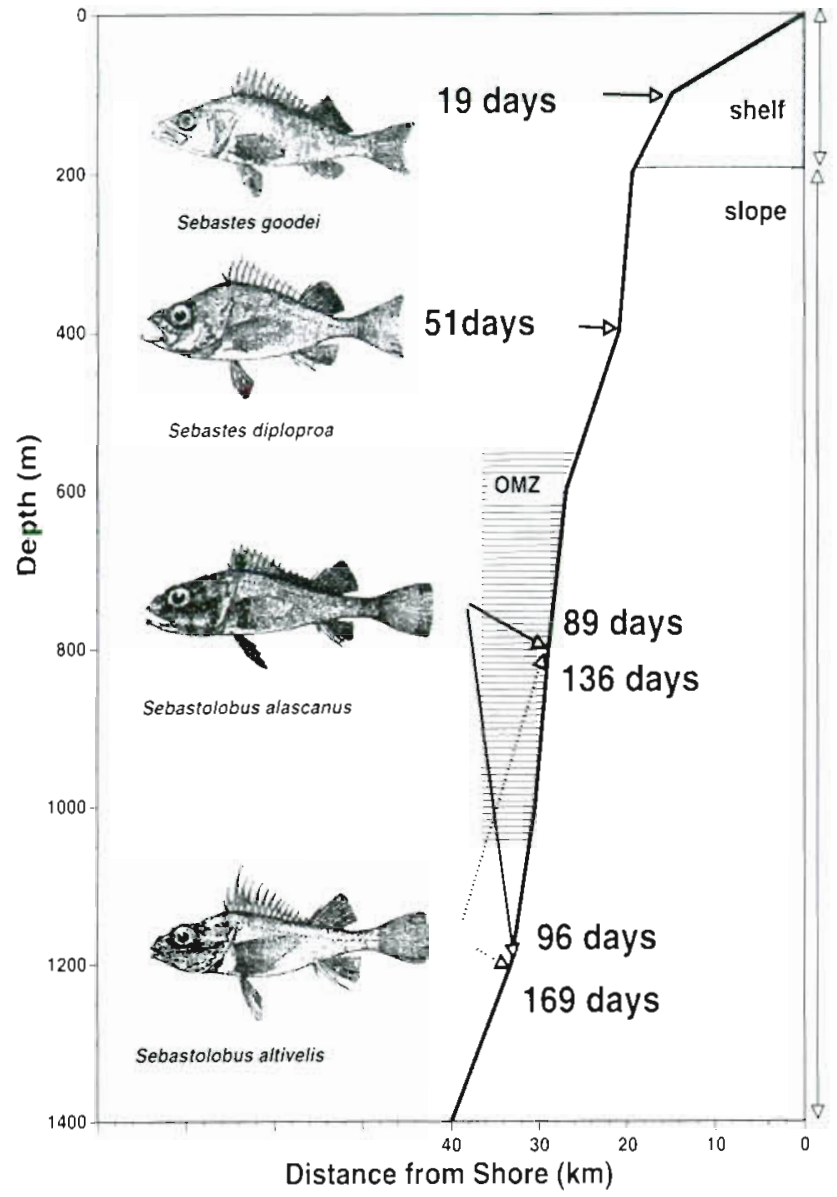

Fig. 8. Sebastes goodei, Sebastes diploproa, Sebastolobus alascanus, Sebastolobus altivelis. Feeding intervals for mecting maintenance energy requirements of specins living at different habitat depths. Feeding interval (d) is for a $200 \mathrm{~g}$ individual consuming a $10 \mathrm{~g}$ meal of either lean-bodıed fish or invertebrate prey. Energy requirements for growth, reproduction, and locomotion are in addition to the costs of maintenance

from the stepwise regression equations in Table 2 . CS activity at our assay temperature $\left(10^{\circ} \mathrm{C}\right)$ was converted to $\mathrm{CS}$ activity at $20^{\circ} \mathrm{C}$ by applying a $\mathrm{Q}_{10}=2$. $\mathrm{CS}$ activity at $20^{\circ} \mathrm{C}$ was converted to oxygen consumption by using the combined regression equation of Yang \& Somero (1993) for Sebastolobus alascanus and Scorpaena guttata. The predicted oxygen consumption rates at $20^{\circ} \mathrm{C}$ were then adjusted to habitat temperature also with a $\mathrm{Q}_{10}$ of 2 . The predicted oxygen and energy consumption rates for $S$ alascanus agree well with those of Yang \& Somero (1993) cited in Table 3. The Sebastolobus altivelis results also agree remarkably well with in situ oxygen consumption measurements made at $1300 \mathrm{~m}$ for $\mathrm{S}$. altivelis (Smith \& Brown 1983) shown in Table 3. By using an oxycalorific coefficient of $19.4 \mathrm{~kJ} \mathrm{O}_{2}$ and an energy content of prey (lipid-poor fish and invertebrates) of $0.2 \mathrm{~g}^{-1}$ (Jobling 1994), we were able to estimate the maximum feeding interval for maintenance metabolism for a $200 \mathrm{~g}$ individual consuming a $10 \mathrm{~g}$ meal (Table 3, Fig 8).

Clearly, metabolic demand decreases markedly as we move from the relatively warm, well lit, food-and oxygen-rich environment of the shelf to the colder. dark, hypoxic slope habitat. Sebastes goodei at $100 \mathrm{~m}$ and $S$. diploproa at $400 \mathrm{~m}$ are separated by only a few hundred meters (Table 3, Fig. 8), yet they show a profound difference in metabolic rate between the shelf and slope. We know that Sebastolobus alascanus is food limited on the slope (Yang \& Somero 1993), so the low maintenance ration reflects food availability, not a preference for a low metabolic rate in the presence of abundant food. This low food availability is probably sufficient explanation for the disappearance of most Sebastes species at the shelf-slope transition (Fig. 2). A topic for future study is the possibility that the energy and oxygen delivery demands of live bearing as a reproductive strategy may limit the depth range of Sebastes in low food, low oxygen habitats

Perhaps more interesting is the observation that 2 species, Sebastolobus alascanus and $S$. altivelis, that look and act so similarly, can have such different metabolic rates when same-sized individuals are compared at the same depths (Table 3, Fig. 8). At $800 \mathrm{~m} \mathrm{~S}$. alascanus needs to eat once every $89 d$ while the samesized $S$. altivelis will only eat once every $136 \mathrm{~d}$.

The bioenergetic demands of the 2 species are also interesting at the population level where differences in mean size and mean density are also considered (Table 3, Fig. 9). At $800 \mathrm{~m}$, the center of the Sebastolobus altivelis distribution, the smaller $S$. altivelis outnumbers $S$. alascanus by about 39 to 1 (Fig. 9a) However, it only requires about twice the energy to maintain such a high density (Fig. 9b). At $1000 \mathrm{~m} \mathrm{~S}$. alascanus remains numerically rare relative to $S$. altivelis (13 to 1), but becomes energetically dominant because of its larger body size and higher weight-specific metabolic rate (Fig. 9b) S. alascanus remains energetically dominant down to $1400 \mathrm{~m}$, the limits of their range (Table 3. Fig. 9)

The estimates for time between feeding, 80 to $90 \mathrm{~d}$. for Sebastolobus alascanus and about 130 to $180 \mathrm{~d}$ for S. altivelis (Table 3, Fig. 8), highlight the low energy nature of the slope habitat relative to the shelf. This is all the more true when we consider that the shelf habitat supports 19 other Sebastes species as well as Sebastes goodei (feeding interval $19 \mathrm{~d}$ ) considered here (Figs. 2 \& 8). The low food encounter rates on the slope emphasize the limitations to various feeding strategies. The diversity and specialization of rockfish feeding habits would be hard to maintain. when successive 
feeding opportunities are available on the order of months (Table 3, Fig. 8). Further, it may be possible to suggest a lower limit to the sit-and-wait feeding strategy. $S$. alascanus, which waits to capture individual epibenthic prey organisms, may have reached the energetic limits of this approach. At deeper depths there is no comparable sit-and-wait predator. Rather, fishes (e.g. macrourids) that specialize in the capture of epibenthic prey items typically employ a slow, cruising search for food.

\section{CONCLUSION}

Our data fit the general pattern that metabolism declines with depth in the sea. By presenting a more complete size and depth range, we have been able to consider the physiological and ecological basis of this decline. In this study and a related study on flatfish (Vetter et al. 1994) we have clearly shown that the coefficients of scaling of enzyme activity with body weight can vary in sign as well as magnitude between related shallow and deep species. This means that depth comparisons must include information on size scaling and that the size of specimens measured must be reported. The opportunity to validate metabolic predictions based on CS activity, by comparison with in situ respirometry (Smith \& Brown 1983), was particularly useful. Childress (1995) summarized the 5 possible factors that might lead to decreases in metabolism with depth. These factors are: (1) increased hydrostatic pressure, (2) decreased food availability, (3) decreased oxygen availability, (4) decreased temperature, and (5) decreased ambient light levels. He argues strongly that the most significant factor is diminished light, acting to relax the need for strong locomotory performance. For benthic fish on the slope, we feel that decreased food availability may be the best explanation for declining metabolism. We make this conclusion based on the plasticity of the metabolic depression and the ability to ameliorate it by increasing ration experimentally. Previous studies of 3 slope species, Dover sole Microstomus pacificus (Vetter et al, 1994), sablefish Anoplopoma fimbria (Sullivan \& Somero 1983), and Sebastolobus alascanus (Yang \& Somero 1993), all show experimental evidence that metabolic depression can be reversed by higher ration. The paradigm of pressure adaptation, where shallowand deep-living congeners express different resistances to hydrostatic pressure, needs further clarification in light of the discovery that large metabolically active $S$. alascanus live in deep water. These large, deep-living fish have not yet been examined for pressure adaptations.

Scorpaenids undergo a rapid decrease in species richness at the transition from the continental shelf to the upper slope. However, some species such as Sebastolobus altivelis are remarkably abundant on the slope. Based on our results, this density does not reflect productivity because of the low energy flow through these populations. It manifests itself as slow growth rates and greater longevity (Butler et al. 1995, discussion in Jacobson \& Vetter 1996). Unless fisheries managers determine sustainable yield on the basis of the unusual bioenergetics of the slope community, these populations are highly susceptible to overfishing.

Acknowledgements. This work was carried out with the help of the crew of the NOAA ship 'David Starr Jordan'. Drs J. R. Hunter, J. Butler, G. Moser, L. Jacobson and E. Goolish provided useful insights and discussions during the course of the study. We thank R. Dodson and R. Lynn for help with the oceanographic measurements. T. Shafer and S. Costa provided help for enzyme assays and data analysis. C. Kimbrell carried out many of the statistical evaluations. References to trade names do not imply endorsement by NOAA.

\section{LITERATURE CITED}

Butler JL, Kastelle C, Rubin K, Kline D, Heijnis H, Jacobson L, Andrews A, Wakefield WW (1995) Age determination of shortspine thornyhead Sebatolobus alascanus, using otolith sections and ${ }^{210} \mathrm{~Pb}:{ }^{226} \mathrm{Ra}$ ratios. Admin Rep LJ-9512. National Marine Fisheries Service, Southwest Fisheries Science Center, La Jolla, CA 
Childress JJ (1995) Are there physiological and biochemical adaptations of metabolism in deep-sea animals? Trends Ecol Evol 10:30-36

Childress JJ, Nygaard MH (1973) The chemical composition of midwater fishes as a function of depth of occurrence off Southern California. Deep Sea Res 20:1093-1109

Childress JJ, Somero GN (1979) Depth-related enzymic activities in muscle, brain and heart of deep-living pelagic marine teleosts. Mar Biol 52:273-283

Eschmeyer WN, Herald ES, Hammann H (1983) A field guide to Pacific Coast fishes. Houghton Mifflin, Boston

Goolish EM (1991) Aerobic and anaerobic scaling in fish. Biol Rev Camb Philos Soc 66:33-56

Goolish EM (1995) The metabolic consequences of body size. In: Hochachka PW, Mommsen TP (eds) Biochemistry and molecular biology of fishes, Vol 4. Elsevier Science, Amsterdam, p 335-366

Hennessey JP Jr, Siebenaller JF (1985) Pressure inactivation of tetrameric lactate dehydregenase homologues of confamilial deep-living fishes. J Comp Physiol B:155 647-652

Ianelli JN, Lauth R, Jacobson LD (1994) Status of the thornyhead (Sebastalobus sp.) resource in 1994. In: Status of the Pacific coast groundfish fishery through 1994 and recommended acceptable biological catches for 1995. Pacific Fisheries Management Council, Portland, OR, p D1-D58

Jacobson LD, Vetter RD (1996) Bathymetric demography and niche separation of thornyhead rockfish: Sebastolobus alascanus and Sebastolobus altivelis. Can J Fish Aquat Sci 50:600-609

Jobling M (1994) Fish bioenergetics. Chapman and Hall, London

Miller DJ, Lea RN (1972) Guide to the coastal marine fishes of California. Calif Dept Fish Game, Fish Bull 157

Moser HG (1974) Development and distribution of larvae and juveniles of Sebastolobus (Pisces: family Scorpaenidae) Fish Bull US 72:865-884

Moser HG, Boehlert GW (1991) Ecology of pelagic larvae and juveniles of the genus Sebastes. Environ Biol Fish 30 203-224

Pearcy WG (1962) Egg masses and early developmental stages of the scorpaenid fish, Sebastolobus. J Fish Res Bd Can 19:1169-1173

Pelletier D, Gugerley H, Dutil J (1993) Does the aerobic capacity of fish muscle change with growth rates? Fish Physiol Biochem 12:83-93

Schmidt-Nielsen K (1990) Animal physiology: adaptation and environment. Cambridge Univ Press, Cambridge

Siebenaller JF (1983) The pH-dependence of the effects of hydrostatic pressure on the $\mathrm{M}_{4}$-lactate dehydrogenase homologs of scorpaenid fishes. Mar Biol Lett 4:233-243

Siebenaller JF (1984) Analysis of the biochemical consequences of ontogenetic vertical migration in a deep-living teleost fish. Physiol Zool 57:598-608

Siebenaller JF, Somero GN (1978) Pressure-adaptive differences in lactate dehydrogenases of congeneric fishes living at different depths. Science 201:255-257

Siebenaller JF, Somero GN (1982) The maintenance of differ-

This article was presented by Nicholas Holland (Senior

Editorial Advisor), La Jolla, California, USA ent enzyme activity levels in congeneric fishes living at different depths. Physiol Zool 55:171-179

Siebenaller JF, Somero GN (1989) Biochemical adaptation to the deep sea. Crit Rev Aquat Sci 1:1-25

Silverthorne W, Jacobson W (1995) Economic status of the Washington, Oregon and California groundfish fisheries. In: Status of the Pacific coast groundfish fishery through 1995 and recommended acceptable biological catches for 1996. Pacific Fisheries Management Council, Portland, OR, p F3-F10

Smith Kl Jr, Brown NO (1983) Oxygen consumption of pelagic juveniles and demersal adults of the deep-sea fish Sebastolobus altivelis measured at depth. Mar Biol 76:325-332

Somero GN (1991) Hydrostatic pressure and adaptations to the deep sea. In: Prosser CL (ed) Comparative animal physiology. John Wiley and Sons, New York, p 167-204

Somero GN (1992) Adaptation to high hydrostatic pressure. Annu Rev Physiol 54:557-577

Somero GN, Childress JJ (1980) A violation of the metabolism-scaling paradigm: activities of glycolytic enzymes increase in larger-size fish. Physiol Zool 53:322-337

Somero GN, Childress JJ (1990) Scaling of ATP-supplying enzymes, myofibrillar proteins and buffering capacity in fish muscle: relationship to locomotory habit. J Exp Biol 149:319-333

Somero GN, Siebenaller JF (1979) Inefficient lactate dehydrogenases of deep-sea fishes. Nature 282:100-102

Sullivan KM, Somero GN (1983) Size- and diet-related variations in enzyamatic activity and tissue composition in the sablefish, Anoplopoma fimbrea. Biol Bull (Woods Hole) $164: 315-326$

Vetter RD, Hodson RE (1982) Use of adenylate concentrations and adenylate energy charge as indicators of hypoxic stress in estuarine fish. Can J Fish Aquat Sci 39:535-541

Vetter RD, Lynn EA, Garza M, Costa AS (1994) Depth zonation and metabolic adaptation in Dover sole, Microstomus pacificus, and other deep-living flatfishes: factors that affect the sole. Mar Biol 120:145-159

Wakefield WW (1990) Patterns in the distribution of demersal fishes on the upper continental slope off Central California with studies on the role of ontogenetic vertical migration in particle flux. PhD thesis, Scripps Institution of Oceanography, University of California San Diego

Wourms JP (1991) Reproduction and development of Sebastes in the context of the evolution of piscine viviparity. Environ Biol Fish 30:111-126

Yang TH, Lai NC, Graham JB, Somero GN (1992) Respiratory, blood, and heart enzymatic adaptations of Sebastolobus alascanus (Scorpaenidae; Teleostei) to the oxygen minimum zone: a comparative study. Biol Bull (Woods Hole) 183:490-499

Yang $\mathrm{TH}$, Somero GN (1993) Effects of feeding and food deprivation on oxygen consumption, muscle protein concentration and activities of energy metabolism enzymes in muscle and brain of shallow-living (Scorpaena guttata) and deep-living (Sebastolobus alascanus) scorpaenid fishes. J Exp Biol 181:213-232

Manuscript received: May 14, 1996

Revised version accepted: May 6, 1997 